\title{
DETERMINANTS OF PROFITABILITY AND FIRM VALUES IN THE MANUFACTURING SECTOR OF FIRMS IN INDONESIA
}

\author{
${ }^{1}$ Hikma Niar, ${ }^{2} \mathrm{H}$. Abdul Rahman Mus, ${ }^{3} \mathrm{Hj}$. Masdar Mas'ud, ${ }^{4}$ Mursalim \\ ${ }^{1}$ Doctoral Student, University of Muslim Indonesia \\ ${ }^{2,3,4}$ Faculty of Economics, University of Muslim Indonesia
}

\begin{abstract}
This study investigates the Determinants of profitability and firm values in the Manufacturing Sector of Firms in Indonesia. A total of 55 companies listed on the Indonesia Stock Exchange were used as samples. Observation data is used from 2014 to 2016. The Structural Equation Modeling Test using analysis of moment structures ver. 22 provides evidence that Investment decisions has a positive and significant effect on profitability but not for firm values. Capital structure has a positive and significant effect on profitability but not for firm values. Company's growth has a positive and significant effect on profitability and firm values and then the last causality is Profitability has a positive and significant effect on firm values.
\end{abstract}

Keywords: Investment decisions, capital structure, growth, profitability, firm values

\section{INTRODUCTION}

Investor confidence towards companies with high investment decision at this time, led to rising demand for stock company, it affects increasing numbers of investors who invested in the company. With increased investment decisions do have an impact on increasing the value of the company and provide high returns coupled with manageable risks, are expected to raise the value of the company, which intends to increase shareholder wealth. For that financial managers are required to be able to manage the company with a good management in order to achieve an optimum level of efficiency of use of capital. Assessment of the efficiency of operations carried out by most of the analysis of the income statement, while the effective use of better resources measured by reviewing the balance sheet and income statement. To ensure that the company's goals can be achieved and determine the effectiveness of the operations company's in achieving the goal (Haruman, 2008).

Company can see how the budget for financing in the future, either by using the capital structure, so that managers are required to develop the capital structure in order to use a combination of 
International Journal of Arts and Humanities

ISSN: 2581-3102

Volume:02, Issue:03 "March 2018"

debt, preferred stock and common stock according to the budget. Total shareholder wealth can be measured by assessing the increase in the number of the shares multiplied by the market price per share (Martono and Harjito, 2000). Thus, if the stock market price increases, the company will increase, indicating that the basic structure means that the capital will be made by the company (Ticoalu, 2013).

The capital structure is the balance or ratio between the number of long-term debt and equity capital. Therefore, financial management should be prudent in making capital structure decisions. Errors in determining the capital structure will have a broad impact, especially when a company is too big to use the debt; the burden remains the company to bear the greater. The optimal capital structure is that minimizes capital costs and maximizes the value of the company. The higher the value the more prosperous companies reflects the company owner. However, based on the theory of capital structure, capital structure when the position is above the target capital structure lengths, then any increase in debt will lower the value of the company. The essence of the trade-off theory of capital structure is to adjust benefits and tradeoffs that arise from the use of debt. As far larger benefits, additional debt is still allowed. When sacrifice for a greater use of debt already, the additional debt is not allowed (Kusumajaya, 2011).

One or other of the expected company growth both stakeholders in the long or short term basis. This causes the level of competition between companies is getting tougher, especially in manufacturing companies. These companies are racing to get the maximum profit from the sale of their products. To achieve this goal must of course be supported by strong capital within the company to support their production process. The growth of manufacturing industry in Indonesia, namely at the beginning of the New Order, the manufacturing industry is relatively slow to growth. That is because the original local industry is still small, almost all types of machines to be imported. Causing the government should provide strict controls on imports, and this restriction is a serious obstacle for building industries. The company's growth is a prospect for any reason the company can provide the positive aspects of the company, as investment will be invested in the hope of providing a high return. Because of this high-growth companies will be interested in its shares by investors (Fanani, 2010). Growth is how far the company put itself in the overall economic system or economic system for the same industry. In general, companies that grow quickly obtain positive results in the competitive world of business, enjoy increased sales significantly and are accompanied by an increase in the market. So companies with a high growth rate require more funds in the future, especially external funding to meet the investment needs and to satisfy the need to finance its growth.

One of the company's values is determined by profit, low profit and quality will decide the users of financial statements to be biased. Profit reflects the ability to make a profit in relation to sales, 
equity and total assets (Soliha and Taswin, 2002). Profit is the main attraction for the owner of the company as a result of the profit earned by the fund management business in investment by shareholders and also reflects the distribution of benefits they are entitled. The size of the profits generated by the company can also affect the prosperity of the company and its shareholders, because of the increased value of the company to attract investors to invest. Companies with high profits, then investors will assess the value of the company increases. To be able to carry out operational activities, the company must be in profitable because of the absence of profit will be difficult for the company to attract capital from outside. Companies with high levels of profitability will demand shares by investors so as to increase the company's value (Mardiyati et al. 2012). The growth of manufacturing companies listed in Indonesia Stock Exchange the upward trend in sales, asset growth has also increased and profit growth volatility. More specifically indicated phenomenon based on the data support the company's growth as follows:

Table 1: Company Growth Manufacturing sector

\begin{tabular}{|l|c|c|c|c|}
\hline \multirow{2}{*}{ Growth } & \multicolumn{3}{|c|}{ Years (Rp) } & \multirow{2}{*}{ Average (Rp) } \\
\cline { 2 - 4 } & 2014 & 2015 & 2016 & \\
\hline Sales & $498.925 .992 .662,71$ & $474.009 .148 .733,49$ & $299.666 .758 .453,10$ & $424.200 .633 .283,10$ \\
\hline Assets & $599.095 .285 .041,29$ & $551.930 .648 .197,01$ & $534.191 .341 .775,59$ & $561.739 .091 .671,30$ \\
\hline Earnings & $838.919 .420,92$ & $20.582 .169 .571,80$ & $10.082 .726 .425,43$ & $10.501 .271 .806,05$ \\
\hline
\end{tabular}

The table shows that the increase Asset and capital does not necessarily give rise to a gain or in other words not guarantee the capital asset and profit growth proportionally.

\section{THEORETICAL FRAMEWORK}

\section{Firm's value}

The general objective of company can be both economic and non-economic (Halim and Mamduh, 2009). The goal is to benefit the economy, to achieve the benefits we have to use different strategies tailored to the functions of the company either in the production, marketing, finance and human resources. The purpose of financial management is to maximize shareholder wealth (wealth maximization of stockholders) by maximizing the value of companies in which the company is willing to pay the price that potential buyer when the company was sold (Brigham and Philip, 2004). Maximize the value of the company is essential for maximizing the company's value also means maximizing shareholder wealth. The company's value will be reflected in its share price. The market price of shares of the company that developed between the buyer and the seller in the event of a transaction referred to the company's market value, as 
International Journal of Arts and Humanities

ISSN: 2581-3102

Volume:02, Issue:03 "March 2018"

the price of the stock market is considered a reflection of the true value of the company's assets (Fama, 1978).

The firms' value is the price that potential buyers are willing to pay when the company was sold (Husnan, 2004). Other scholars view describes the company as the market value of debt and equity securities of companies that are outstanding (Keown, 2004). The value of many companies interpret meaning that the value of the company reflects the present value of the expected income in the future and reflects the value of the company is the result of a decision taken by the financial manager of the company's stock price. The increased value of the company is an achievement, in accordance with the wishes of the owner, due to the increased value of the company, the welfare of the owners will also increase. The value of the company is very important because of the high value of the company which will be followed by a high prosperity shareholder. The higher the stock price the higher the value of the company. The high value of the company to the wishes of the owner of the company, for a high score indicates prosperity shareholders also high (Keown 2000: 555).

The company's growth has a positive effect on the firm value, that sales growth had a positive effect on the PER and market to book value. The company grew quickly obtain positive results world competition, enjoyed sales increases significantly and is accompanied by an increase in the market (Beiner et al. 2004). The company's growth is contributed optimally to human resources (Machfoedz, 1996; 36). Each company is constantly striving to improve profitability, it's because the higher the level of profitability of an enterprise the survival of these enterprises will be more secure (Safrida, 2008). Previous research findings show that the capital structure positive and significant effect on profitability, the Company growth positive and significant effect on profitability, the capital structure positive and significant effect on firm value, the company's growth positive and significant impact on the firm value (Kusumajaya, 2011).

\section{The investment decision}

Company is a mix between real assets to the investment options in the future. The meaning of this theory gives the impression that the company is closely related to the investment. The investment project is a plan to invest the resources, both gigantic projects and small projects to benefit in the future. In most cases these benefits in the form of money (Smith and Watts, 1992; Husnan, 1996: 5). Financial managers should help companies identify promising projects and decide how much wills the investment in each project. On the other hand investment decisions also referred to the decision of the capital budget, because most companies provide an annual operating budget consists of capital investment Certificate (Brealey et al, 2008: 4). The investment decision-making concerning the allocation of funds both funds from the company and the funds that come from outside the company in various forms of investment both short-term 
International Journal of Arts and Humanities

ISSN: 2581-3102

Volume:02, Issue:03 "March 2018"

investments and long-term investments (Ningsih and Indarti, 2012). Investment can reflect the company's growth in economic activity and business conduct. Decision-making on investments is usually difficult, since it requires an assessment of the situation in the future that are not easy to predict because of the uncertainty in the future (Ayuningtyas, 2013).

Financial managers should help the company to identify projects that promise and decided how many will be on investment in each project; the investment decision is referred to the decision of the capital budget because most companies provide an annual operating budget consists of capital investment Certificate (Brealey et al. 2006). Empirical evidence shows that the higher the level of investment activity reflects the breadth of investment opportunities and increasing the company's operating results shown on the company's ability to earn income from operations. High operating profit reflects the ability generated by a number of assets owned, investment decisions significant and positive impact on the company (Yuliani et al. 2013). Investment decisions related to the process of selecting one or more alternative investment is considered beneficial from a number of investment alternatives available to the company. So it can be said that the investment decisions affecting the company as a good investment composition will be able to attract investors to invest in the company (Yuliani et al. 2013).

Investment decision in this study is the proxy for Price Earnings Ratio (PER). PER is high for a good investment and good growth prospects of the company so that investors will be interested. The high demand for shares will make investors appreciate the value of the shares is higher than the value recorded on the balance sheet of the company, so the company PBV high and the company is high. The value of a company depends on the company's production in the future (Fitriana and Pangestuti, 2014). Investment decisions positively and significantly to the value of the Company (Fenandar and Raharja, 2012; Qadariah, 2013).

$\mathrm{H}_{1}$ : The investment decision is a positive and significant effect on profitability

$\mathrm{H}_{2}$ : The investment decision is a positive and significant effect on firm values

\section{Capital Structure}

The capital structure is a mixture or blend of debt, preferred stock, common stock of that company in the capital structure of the company (Brigham and Houston, 2010: 150). The same view was expressed that the structure of capital expenditure remained reflected through the balance between equity capital and long-term debt (Riyanto, 2010: 22). Optimal capital structure of a company is defined as a structure that will maximize a company's stock price. The capital structure of the company concluded a funding mix to be in the good governance so as to maximize the value of a company (Brigham and Houston, 2010: 155). 
International Journal of Arts and Humanities

ISSN: 2581-3102

Volume:02, Issue:03 "March 2018"

The capital structure of the company can be analyzed using the Earnings before Interest and Taxes (EBIT) and Earning per Share (EPS) to find common ground (indifference point) and use the leverage ratio (Sjahrial, 2007: 179). It can be concluded that the capital structure is a composition of their own capital with long-term debt in financing income. The results in the selection of the source of funds are important because it will affect the company's capital structure, which ultimately will affect profits. Capital structure decisions are done improperly will cause fixed costs in the form of high capital, which in turn can lead to low profitability (Kusumajaya, 2011). High profitability of companies will have more internal funds of the company's low profitability. So when the composition of the capital structure of its own capital is greater than the debt, the ratio of capital structure will be smaller. The ratio of capital structure is measured by Debt to Equity Ratio (DER). If Debt to Equity Ratio increased, the ability of the company to benefit will be lower, so the DER has a negative correlation with profitability. Results of previous studies provide evidence that the capital structure and significant positive effect on the value of the company (Kusumajaya 2011; Hermuningsih 2012; Dewi et al. 2014). The decision was in contrast to the findings of other researchers, that the capital structure does not affect the firm value (Suryani, 2015).

$\mathrm{H}_{3}$ : The capital structure is a positive and significant effect on profitability

$\mathrm{H}_{4}$ : The capital structure is a positive and significant effect on firm values

\section{Company Growth}

The company growth is how far the company put itself in the overall economic system or economic system for the same industry (Machfoedz, 1996). The opinion has the meaning that the company's growth happens when companies put themselves in the overall economic system or economic system for the same industry. The growth was due to the company's funds flow from operational changes due to growth or decline in business volume (Helfert, 1997). Other scholars view (Copeland, 2008: 124) growth is the company's ability to increase the size. So the company's growth can be defined as an increase in a company.

A company in the industry that has a high growth rate should provide sufficient capital to fund the expenses of the company. Fast growing company tends to use more debt than a company that develops slowly (Weston and Brigham, 1997). The level of opportunity to develop a fast growing company will be able to find a way that the company is in a development. The growth of companies is constantly increasing and the increase in value of the assets is expected to drive the expectations of investors for investment opportunities with expected benefits to be achieved. A newly established company or a small company at the level of sales growth increased demand for asset additions, as growth will not occur as expected without an increase in its assets. 
International Journal of Arts and Humanities

ISSN: 2581-3102

Volume:02, Issue:03 "March 2018"

Moreover, growth in assets is usually financed with additional debt or new capital (Sartono, $2008 ; 216)$. Growth is expressed as the total assets in the total assets of the past which will describe the benefits that will come and the growth that will come (Soliha and Taswin, 2002). The asset growth reflects the growths of the company's assets which will affect the company's profits were convinced that the percentage change in total assets is a better indicator to measure the growth of the company (Yudi and Rina, 2012).

Empirical evidence suggests that growth affect profits. The discovery explains that the assets held to have an effect on productivity and efficiency, which in turn have an effect on profits. Total assets as determined by considering the size of the growth is relatively stable compared to the value of assets market value capitalized and sales. So asset growth is calculated as the percentage change in assets at some point over the previous year (Kusumajaya 2011). The company's growth has a direct and positive influence on stock price movements. (Darwiah, 2010). The company's growth has a direct and positive impact on the changing value of the company (Myers and Bacon, 2002; Darwiah, 2010; Nurdin, 2013). Some of the findings of other researchers objected, that the company's growth does not affect the value of the company (Suriyani, 2015).

$\mathrm{H}_{5}$ : The company growth is a positive and significant effect on profitability

$\mathrm{H}_{6}$ : The company growth is a positive and significant effect on firm values

\section{Profitability}

The profitability ratio will give an idea of the effectiveness of the company's management. The higher gain means the better, because the prosperity of the owner of the company with increasing profitability. High profitability shows good prospects for the company so that investors will give a positive response signal and the company rose (Soebiantoro and Sudjoko, 2007). The purpose of the analysis is to analyze the differences gain in operating profit due to the growth factor. The net effect on operating profit growth is a combination of the effects of the growth of sales revenue and operating costs (Blache et al. 2005).

Companies with high returns on investment using a relatively small debt. Higher rates of return allow financing the bulk of the funding requirements with internally generated funds (Brigham and Houston, 1997). The higher the level of profitability of a company the greater the level of prosperity provided by the company will attract investors to the company and will have a positive impact on stock prices in the market. This means that it will raise the value of the company. Kusumajaya (2011) revealed that the ratio of profit or profitability ratio shows the company's success in generating profits. In this study, the benefits are measured by return on equity (ROE) ratio is very important for the owners of the company (the common stockholder), 
International Journal of Arts and Humanities

ISSN: 2581-3102

Volume:02, Issue:03 "March 2018"

as this ratio shows the level of return generated by the management of capital provided by the owners of the company. In other words, ROE shows the benefits that will be enjoyed by shareholders. Empirical evidence shows that profits have a significant effect in improving the company Kusumajaya, 2011; Rizqia and Sumiati, 2013; Firmansyah, 2015).

$\mathrm{H}_{7}$ : The profitability is a positive and significant effect on firm values

\section{METHODS}

This research uses explanatory research approach. This study was conducted at the Indonesian Stock Exchange on the manufacturing industry companies listed on the Indonesia Stock Exchange (IDX) with years of observation is 2014 to 2016. The data used stems from the Indonesian Capital Market Directory (ICMD). The criteria used in the extraction of samples, one of which is the Company did not incur losses during 2014 - 2016, which will cause the company to be low in order to obtain a sample of 55 companies. Hypothesis testing is done using Structural Equation Modeling (SEM) with AMOS 22

\section{RESULTS}

\section{Investment decisions effect on profitability}

Tests on the hypothesis $1\left(\mathrm{H}_{1}\right)$ who stated that investment decisions have an effect on profitability is accepted, can be proved by the path coefficient 0,527 and with the p-value 0.000 $<0.05$. It can be construed that the right investment decisions lead to higher company profits, first proposed the hypothesis that proved acceptable that investment decisions is positive and significant effect on the profitability.

The cause of the significance of cause and effect between these variables because as managers in decision making attempts to provide reinforcement that investment decisions are always based on the book value of fixed assets. The results of this study support the findings of previous research that the higher level of investment activity reflects the breadth of investment opportunities and increasing the operating results of the company (Yuliani et al. 2013).

\section{Investment decision effect on firm values}

Tests on the hypothesis $2\left(\mathrm{H}_{2}\right)$ which states that investment decisions have an effect on firm values can be proven otherwise rejected by the path coefficient of 0.130 and the p-value $0.152<$ 0.05 , so it can be explained that investment decisions do not contribute to the company. The study's findings refute the findings of previous research, that investment decisions relating to the process of selecting one or more alternative investment is considered beneficial from a number of investment alternatives available to the company (Yuliani et al. 2013). 
International Journal of Arts and Humanities

ISSN: 2581-3102

Volume:02, Issue:03 "March 2018"

The situation is caused because taking monetary policy at the company's manufacturing industry has always considered investment decisions with respect to the increase in the book value of fixed assets and total assets of the company to influence the level of the company, but a sample of the company and the indicator in the study showed that taking investment decisions tend considering the benefits without paying attention to the value of shares that can not affect the value of the company. This research is based on the Ferlic (2008) which states that there is a negative correlation between investment decisions of companies with the financial resources of the company. The results of this study rejects the findings of other researchers, that the investment decision is positive and significant impact on the value of the Company (Fenandar and Raharja, 2012; Qadariah, 2013).

\section{The capital structure effect on profitability}

The hypothesis $3\left(\mathrm{H}_{3}\right)$, capital structure affect on profitability of proven otherwise accepted or supported by empirical evidence. The path coefficient of 0.230 and p-value of $0.032<0.05$, so it can be stated that the capital structure of the company can increase profits. This study supports the findings Kusumajaya (2011) that the capital structure and significant positive effect on the company. The situation is caused because the capital structure that is done improperly will cause fixed costs in the form of high capital, which in turn can result in lower profits.

The owner can use a considerable debt to limit its managers. High debt ratio will increase the threat of bankruptcy to be more careful and not waste money shareholders. The results in the selection of the source of funds are important because it will affect the company's capital structure, which ultimately will affect profits. Capital structure decisions are done improperly will cause fixed costs in the form of high capital, which in turn can lead to low profitability (Kartini and Arianto, 2008).

\section{The capital structure effect on firm values}

The hypothesis $4\left(\mathrm{H}_{4}\right)$, capital structure positive and significant effect on firm values is not supported by empirical evidence. The path coefficient is a 0.072 and then the p-value $0.452>$ 0.05 , so it can be stated that the capital structure does not contribute to the company. This study refutes the findings of researchers (Kusumajaya 2011; Hermuningsih 2012; Dewi et al. 2014) that the capital structure and significant positive effect on the value of the company at the company. The results of this study are relevant to the findings of other researchers, that the capital structure does not affect the value of the company (Suriyani, 2015).

\section{The company's growth effect on profitability.}


International Journal of Arts and Humanities

ISSN: 2581-3102

Volume:02, Issue:03 "March 2018"

The hypothesis $5\left(\mathrm{H}_{5}\right)$, which states that the company's growth and significant positive effect on the profitability of proven otherwise received and supported by empirical facts. The path coefficient of 0.250 and $p$-value of $0.001<0.05$, so it can be stated that the company's growth contributed to the increase in company profits. The study's findings are relevant to the study results prove that Growth affect profits. That the company with its assets to increase productivity and efficiency, which in turn affects the profit (Darwiah 2010; Kusumajaya, 2011)

\section{The company's growth effect on firm values}

The hypothesis $6\left(\mathrm{H}_{6}\right)$, company's growth had a positive and significant on firm values proven otherwise accepted or supported by empirical facts. The path coefficient of 0.187 with a p-value of $0.023<0.05$, so it can be stated that the company's growth can contribute to the increased value of the company. These findings support previous research studies conducted that growth companies have a positive influence on the company (Myers and Bacon, 2002; Darwiah 2010; Nurdin, 2013). Rejecting the findings of other researchers, that growth does not affect the value of the company (Suriyani, 2015).

The company's growth in terms of sales growth, asset growth and profit growth, direct and significant positive effect on the company. It is envisaged that the better the sales growth and the market value of the company's assets is increasing and ultimately increase profit growth. States are required to enhance the company's growth through increased sales growth; profit growth, asset growth and that directly affect significantly the value of the company.

\section{Profitability effect on firm values}

The hypotheses $7\left(\mathrm{H}_{7}\right)$ which states that the profit positive and significant impact on the company's proven otherwise accepted or supported by empirical facts. The path coefficient of 0.259 with a p-value of $0.019<0.05$, so it can be stated that profitability could increase the company's value. The findings of this study support the findings of previous research that the higher the return, the higher the company's ability to generate profits and will create high corporate profitability (Firman, 2015; Kusumajaya 2011; Rizqia and Sumiati, 2013; Fitriana and Pangestuti, 2014).

\section{CONCLUSION}

Investment decisions are measured by indicators Gross Book Value of Property, Plant, and Euipment to the Book Value of the Assets Ratio (PPE / PBA), Market to Book Value of Equity Ratio (MVA / BE), Market to Book of Assets Ratio (MVA / BVA) and the Additional Capital to Assets Book Value Ratio (CAP / BVA) proved to increase the profitability of manufacturing companies listed in Indonesia Stock Exchange. Capital structure, as measured by indicators of 
International Journal of Arts and Humanities

ISSN: 2581-3102

Volume:02, Issue:03 "March 2018"

Debt to Equity Ratio (DER), Debt to Total Assets Ratio (DAR), Long Term Debt to Equity Ratio (LTDER) and Market Debit Equity Ratio (MDE) has a positive effect on profitability.

The company's growth as measured by indicators of sales growth, asset growth and profit growth proved to increase the profitability of the company. Profitability consisting of indicator: Net Profit Margin (NPM), Gross Profit Margin (GPR), Return on Assets (ROA) and Return on Equity (ROE) proven to increase the firm value as measured by the Price Earning Ratio (PER), Asset Market to Book Ratio (MBA) and Price Book Value (PBV).

The study recommends to researchers continued expanding the research by extending the study period by increasing the years of observation and also expanding the number of samples for future research. Then do some research development by developing the research model, the model hypotheses or development of multiple variables wider scope in analyzing the profitability and firm values.

\section{REFERENCES}

[1] Ayuningtyas, I. (2014). Effect of Total Asset Turn Over Ratio and Debt Equity Ratio on the Audit Delay in Return on Assets As moderating variables On Property and Real Estate Company listed on the Indonesia Stock Exchange during 2011 - 2013 Year.

[2] Beiner, S., Drobetz, W., Schmid, F., and Zimmermann, H. (2004). Size of board is an independent corporate governance mechanism ?. Kyklos, 57 (3), 327-356.

[3] Blache, ES, Chen, KH, \& Lin, TW (2005). Cost Management: A Strategic Emphasis.

[4] Brealey, RA, Myers, CS, \& Allen, F. (2006). Corporate Finance, 8 upplagan.

[5] Brealey, RA, Myers, SC, and Allen, F. (2008). Principles of Corporate Finance, New York, McGraw-Hill.

[6] Brigham and Houston. (2010). Fundamentals of Financial Management Book 1 (second edition). Jakarta: Four Salemba.

[7] Brigham and Weston J.Fred. (1997). Basics of financial management, edition. Volume 1, Jakarta;

[8] Erland Brigham, Eugene F. and Philip R. Daves. (2004). Intermediate Financial Management. Eighth Edition. McGraw-Hill Inc., New York.

[9] Darwiah, Mahmud. (2010). Effect of Financial Policy of the Company to Realize Value Growth PT. Bank Negara Indonesia (Persero) Tbk in Southeast Sulawesi

[10]Dewi, P. Y. S., Yuniarta, G. A., AK, S., and Atmadja, A. T., SE, A. (2014). Effect of Capital Structure, Company Growth And Profitability Of The Company Value Company LQ 45 In BEI Period 2008-2012. Jimat (Scientific Journal of Accounting Students) Undiksha, 2 (1).

[11]Fama, E. F, (1978). The effects of a firm's investment and financing decisions on the welfare of its security holders. The American Economic Review, 272-284. 
International Journal of Arts and Humanities

ISSN: 2581-3102

Volume:02, Issue:03 "March 2018"

[12] Fanani, Z. (2010). Analysis of the determinants of earnings persistence. Journal of Accounting and Finance Indonesia, 7 (1), 109-123.

[13] Fenandar, GI, and Rahardja, S. (2012). Influence Investment Decisions, Decisions Funding and Dividend Policy Against Corporate Values (Doctoral dissertation, Faculty of Economics and Business).

[14]Ferlic, F. (2008). The growth corridor: a multi-perspective of the optimum model of firm growth.

[15] Firmansyah, I. (2015). Determinant of non-performing loans: The case of Islamic banks in Indonesia. Bulletin of Monetary Economics and Banking, 17 (2), 241-258.

[16] Fitriana, PM, and Pangestuti, IRD (2014). Influence Investment Decisions, Decisions Funding and profitability of the Company Value: Dividend Policy As an intervening variable (Study at Manufacturing Companies Listed on the Stock Exchange Period 20092012) (Doctoral dissertation, Faculty of Economics and Business).

[17] Halim, Abdul and Mamduh M. Hanafi. (2009). Financial Statement Analysis. Edition. 4. UPP STIM YKPN. Yogyakarta

[18] Haruman, T. (2008). Effect of Ownership Structure and Financial Decision Against Corporate Values Survey on Manufacturing Company in Indonesia stock exchange.

[19] Helfert, Erich A. (1997). Financial Analysis Techniques. Translation, Herman. Wibowo. The eighth edition. Erland. Jakarta.

[20]Hermuningsih, S. (2012). Influence Profitability, Size Of Values Company With Capital sruktur As an intervening variable. Business strategy Journal, 16 (2).

[21]Husnan, Suad. (1996). Financial Management Theory and Application (Decision-Term, Long). Fourth Edition, First Book, Yogyakarta: BPFE UGM.

[22]Husnan, Suad. (2004). Fundamentals of Securities Portfolio Theory and Analysis. Yogyakarta: UPP AMP YKPN.

[23] Kartini, K., and Arianto, T. (2008). Ownership Structure, Profitability, Growth Assets and Company Size Of Capital Structure On Manufacturing Company. Journal of Finance and Banking, 12 (1).

[24] Keown, AJ (2005). Financial Management: Principles - Basic Principles and. Application. Volume 2. Indeksh PT Gramedia Group. Jakarta

[25] Keown, AJ (2004). Financial Management: Principles and Applications. Jakarta: PT. Gramedia Group Index

[26] Kusumajaya, D.K.O (2011). Effect of capital structure and growth of the company to profitability and corporate value in manufacturing companies on the stock exchanges in Indonesia. Udayana University.

[27] Machfuedz, M. (1996). Management Accounting Planning and Decision Making ShortTerm. The fifth edition. Book 1. STIE Widya Wiwaha. Yogyakarta. 
International Journal of Arts and Humanities

ISSN: 2581-3102

Volume:02, Issue:03 "March 2018"

[28] Mardiyati, U. Ahmad, GN, and Putri, R. (2012). Effect of Dividend Policy, and Profitability Against Debt Policy Value Manufacturing Companies Listed in Indonesia Stock Exchange (BEI) Period 2005-2010. JRMSI-Indonesia Management Science Research Journal, 3 (1), 1 17.

[29] Martono and Agus Harjito, (2000), Financial Management, Prints 2, Yogyakarta: Ekonisia.

[30] Myers, M., and Bacon, F. (2002). The determinants of corporate dividend policy. In Allied Academies International Conference. Academy of Accounting and Financial Studies. Proceedings (Vol. 7, No. 1, p. 105). Jordan Whitney Enterprises, Inc.

[31] Ningsih, P. P., \& Indarti, I. (2012). Influence Investment Decisions, Decisions Funding, And Dividend Policy Against Corporate Values (Case Study at Manufacturing Companies Listed on the Indonesia Stock Exchange Period 2007-2009). Journal of Accounting and Business Studies, 1 (1).

[32] Nurdin, B. Muh. (2013), Effects of Financial Decisions and Governance on the Growth and Value in the Manufacturing Industry Listed in Indonesia Stock Exchange

[33] Qodariyah, SL (2013). Influence Investment Decisions, Decisions Funding and Dividend Policy Against Corporate Values. Accounting journal. Economics and Business Faculty. Syarif Hidayatullah State Islamic University Jakarta.

[34] Riyanto, Bambang. (2010). Basics Company Spending, ed. 4, BPFE-. Yogyakarta.

[35]Rizqia, D.A, and Sumiati, SA (2013). Effect of Managerial Ownership, Financial Leverage, Profitability, Firm Size, and Investment Opportunity on Dividend Policy and Firm Value. Research Journal of Finance and Accounting, 4 (11), 120-130.

[36] Safrida, E. (2008). Effect of capital structure and growth of the company to the value of the company at a manufacturing company in Jakarta Stock Exchange (Master's thesis).

[37]Sartono, Agus. (2008). Financial Management Theory and Applications Edition Four. Yogyakarta: BPFE Sjahrial, D. (2007). Financial management. Partners Media Discourse. Jakarta.

[38] Smith Jr., CW, and Watts, RL (1992). The investment opportunity set and corporate financing, dividend, and compensation policies. Journal of Financial Economics, 32 (3), 263-292.

[39] Soebiantoro, U. and Sudjoko. (2007). "Effect of Shareholding Structure, Leverage, Factor Internal And External Factors Against Corporate Values". Journal of Management and Entrepreneurship Vol 9.

[40] Soliha, Euis and Taswan. (2002). Effect of Debt Policy Against Corporate Value And Some Factors Affecting. Journal of Management. Vol. 8, No.2. Suryani, MV (2015). Effect of Capital Company Growth And Structure Of Company Value (Case Study Manufacturing Sector Company listing in Indonesia Stock Exchange 2010-2013) (Doctoral dissertation, Semarang State University). 
International Journal of Arts and Humanities

ISSN: 2581-3102

Volume:02, Issue:03 "March 2018"

[41] Ticoalu, RMA (2013). Factors influencing Capital Structure of the Company At the Agriculture Sector Listed on the Indonesia Stock Exchange Period 2007-2011. Calyptra, 2 (2), 1-21.

[42] Weston, JF and Copeland. (2008). Basics of Financial Management Volume II. Erland. Jakarta

[43] Yudi Krisnanda Putra, Y., and Rina Tjandrakirana, R. (2012). Financial Performance Comparison between Bank Syariah Conventional Banks during Global Crisis. Journal of Management and Business Sriwijaya, 10 (20), 27-40.

[44] Yuliani, YL, Isnurhadi, I., and Bakar, SW (2013). Investment decision, financing, and dividends to the value of the company with the business risk as a mediating variable. Journal of Finance and Banking, 17 (3), 362. 